DOI https://doi.org/10.18551/rjoas.2017-02.21

\title{
DETERMINANTS OF PRODUCTIVITY OF SMALLHOLDER FARMERS SUPPLYING CASSAVA TO STARCH PROCESSORS IN NIGERIA: A BASELINE EVIDENCE
}

\author{
Ojiako Ifeanyi A. ${ }^{1 *}$, Tarawali G. ${ }^{2}$, Okechukwu R.U. ${ }^{2}$, Chianu J. ${ }^{1}$ \\ ${ }^{1}$ African Development Bank, Abidjan, Cote d'Ivoire \\ ${ }^{2}$ International Institute of Tropical Agriculture, Ibadan, Nigeria
}

*E-mail: iojiako2008@live.com

\begin{abstract}
The influence of socioeconomic and other household characteristics on the productivity of smallholder farmers supplying cassava to the major commercial starch processors in Nigeria were examined. A multi-stage random sampling technique was used to select 96 farmers working in clusters in selected eight cassava producing states. Data were analyzed using a combination of descriptive and inferential statistics, and multivariate regression techniques. Results revealed the calculated average yield to be $12.39 \mathrm{t} /$ ha thereby leaving an average yield-gap of $7.61 \mathrm{t} /$ ha when compared with an average of $20 \mathrm{t} /$ ha being promoted for farmers under the project. Use of improved varieties $(p<0.01)$ and full-time farming $(p<0.05)$ had significant positive influence on productivity. Also, training, credit use and marital status of farmers influenced productivity positivity at $p<0.10$ levels. Productivity increased with increase in the variables, but the degree of responsiveness was inelastic in each case. Together the included variables explained $72.1 \%$ of the variation in the productivity model. The use of improved cuttings should be accompanied by rigorous but appropriate capacity enhancement programmes to update farmers on modern issues on cassava production and farm management. Empowerment of farmers through linkage to sources of soft loan and other microcredit facilities was recommended, but such efforts should be targeted more on the married and full-time farmers for greater impact.
\end{abstract}

\section{KEY WORDS}

Farmers' characteristics, cassava productivity, yield-gap, full-time farmer, starch processors, Nigeria.

Cassava (Manhihot esculenta Crantz) is a reputable food security crop in tropical Africa. In Nigeria, it ranks high among the major perennial root crops and, in fact, has been described as the third important staple after rice and maize. The cassava plant grows best in well-drained loamy soils and where the annual rainfall ranges of $1,000 \mathrm{~mm}-1,500 \mathrm{~mm}$ and temperature from $25^{\circ} \mathrm{C}-29^{\circ} \mathrm{C}$ (Onwueme, 1978). On the nutritional value, cassava is very rich in carbohydrate providing about $70 \%$ of the total calorie intake for more than one-half of the Nigerian population (Ikwelle et al., 2003; Nweke et al., 1995). Apart from providing food for Nigeria's dense urban, semi-urban and rural populations, cassava and cassava-based businesses provide income, employment, and raw materials for agro-based micro-, smalland medium-scale enterprises (MSMEs). Included in the industrial cassava products are starch, high-quality cassava flour (HQCF), glucose syrup, chips, and ethanol.

Nigeria ranks first among world's producers (UNIDO, 2006). Also, Phillips et al. (2004) wrote that the country's production capacity was one-third more than the production of Brazil and almost double the potentials of Indonesia and Thailand. In the same vein, Nigeria's cassava production was deemed higher in comparison to the production of other African countries, including the Democratic Republic of the Congo, Ghana, Madagascar, Mozambique, Tanzania and Uganda (Phillips et al., 2004). The country's actual production for 2008 was put at over 44.5 million metric tonnes (MT) (FAO, 2012). However, this figure dropped by $17.30 \%$ to 36.8 million in 2009 before rising further to 42.5 million MT in 2010 and 54.0 million MT in 2012. But, as revealed by the available FAO time series data ${ }^{6}$ (FAO, 2012), the recorded growth trend in production was more reflective of increase in land area 
cultivated rather than increase in productivity. The graphical presentation of the growth patterns in Nigeria's cassava production, area cultivated and yield is presented in Figure 1 for 1961-2012.

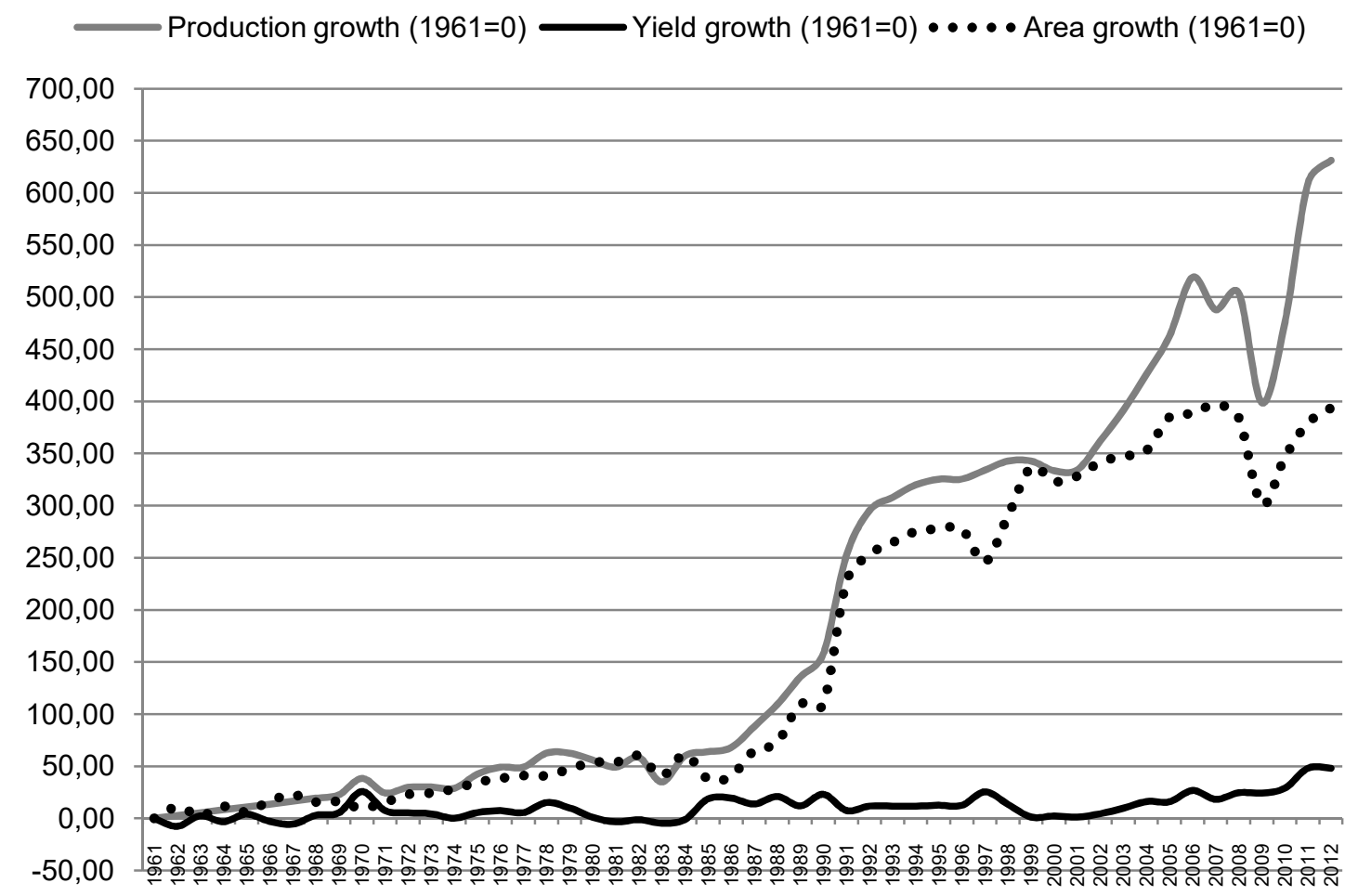

* Growth rate with 1961 as base year (\%)

Figure 1 - Growth trends in cassava levels of output, area and yield, 1961-2008

The Figure shows that there was a similar growth trend for production and area cultivated. However, the growth pattern for yield was observably different. On the average, a growth of $171.5 \%$ was recorded for output level between 1961 and 2008. The average growth in area cultivated was $144.8 \%$ while that of yield was mere $8.6 \%$. Between 2008 and 2012 , although the output had increased by $21.12 \%$ from 44.5 to 54.0 million MT, there was a less than corresponding increase of $18.9 \%$ in the yield during the same period. During the entire 1961-2012 period, the calculated correlation coefficient for growth rates in production and cultivated area was high at $r=0.98$ and statistically significant $(p<0.01)$ as against $r=0.68$ for growth in production and yield, which was also significant $(p<0.01)$. The inference from the observed trend is that land area rather than productivity increase had had more influence in driving the growth in output levels overtime. Thus, efficiency was still very far from being attained as the average yield had remained at a very low level. Suffice this to say that the rallying point of any pro-poor policy and programs in the form of interventions and investments in the cassava value chain, should be to address the challenges of low yield and low productivity of smallholder farmers.

To press this further, it will be justifiable to seek and have a better understanding of the factors that drive the productivity of the smallholder cassava farmers. Much may have been documented already on the influence of the climatic variables, like temperature, sunshine, rainfall, relative humidity, air, and wind, as well as agronomic variables of soil type, soil fertility and typology, fertilizer, planting materials, planting time, quantity and timing of herbicides, among others, on cassava productivity (Ojiako, et al., 2014; FAO, 2013; Aina et al., 2007). But, in addition to these, it has been concisely argued that knowledge of the socioeconomic and other personal characteristics of the farmers enables planners and policy makers to appreciate and develop more user-friendly policies and strategies that will enhance productivity (Ajah and Ajah, 2014; Ajewole and Aiyeloya, 2004). 
Consequently, the following questions may be pertinent: What are the personal socioeconomic and demographic characteristics of smallholder cassava farmers that influence their farming outcomes? What is the nature and magnitude of such influence? The general objective of this study is to analyze the productivity of the smallholder cassava farmers supplying roots to starch processors in southern area of Nigeria. The specific objectives are to determine the yield of smallholder cassava farmers; identify the farmers' personal and socio-economic characteristics that influence their farm productivity; and analyze the responsiveness of yield to changes in the determining factors. It is expected that the result of the study will serve as an enviable policy tool for government agricultural ministries, departments and agencies (MDAs), extension personnel, development agencies and partners, non-governmental organizations (NGOs), community development organizations (CDOs), and other stakeholders in the cassava value chain promotion business.

\section{LITERATURE REVIEW}

Smallholder farmers' characteristics have been distinguished among the factors influencing their capability and on-farm productivity. Literature is rich with past works aimed at explaining the type and nature of these influences. Among the measures of productivity that had been used include the smallholder's farm income (as in Schreinemachers et al., 2016; Ibitoye and Onimisi, 2013), yield (as in Adeniyi and Ogunsola, 2014; Adesoji and Farinde, 2006), farm produce or output levels (as in Olukunle, 2016; Anigbogu et al., 2015; Ayoola et al., 2011; Simonyan et al., 2011); Onemolease and Ataraire, 2005), and profitability (as in Olukunle, 2016). Different crops and value chains had attracted the investigators' interests. Among these are cocoa (Adeniyi and Ogunsola, 2014; Oluyole and Sanusi, 2009), rice (Ajah and Ajah, 2014; Ayoola et al., 2011), maize (Simonyan et al., 2011), cassava (Olukunle, 2016), poultry (Ibitoye and Onimisi, 2013), guinea corn (Onemolease and Ataraire, 2005), and vegetables (Schreinemachers et al., 2016). The list is not in any way exhaustive. However, there were other studies that were not based on any specific value chain, but rather investigated the causality for a basket of crops. For example, Adesoji and Farinde (2006) analyzed determinants of agricultural productivity of a basket of popular arable crops that included maize, cowpea, yam, rice and cowpea in Osun State, Nigeria while Obasi et al. (2013) conducted similar analysis for arable crop farmers in Imo State, Nigeria. Yet in another, Anigbogu et al. (2015) investigated the cooperative farmers in Anambra State, Nigeria in a study that measured productivity based on the farmers output levels.

The efforts had led to mixed conclusions. Among the factors that were variously identified for their positive influence on productivity are farmer's age (Anigbogu et al., 2015; Adeniyi and Ogunsola, 2014; Ayoola et al., 2011), education, training and demonstrations (Schreinemachers et al., 2016; Anigbogu et al., 2015; Ibitoye and Onimisi, 2013; Simonyan et al., 2011; Adesoji and Farinde, 2006), farming experience (Anigbogu et al., 2015; Obasi et al., 2013; Ayoola et al. 2011), full-time farming (Onemolease and Ataraire, 2005) income (Anigbogu et al., 2015), marital status (Simonyan et al., 2011), and farm size (Olukunle, 2016; Obasi et al., 2013; Oluyole and Sanusi, 2009). Other positive determinants were extension contact (Obasi et al., 2013; Simonyan et al., 2011), fertilizer use, including chemical and organic fertilizer (Anigbogu et al., 2015; Adeniyi and Ogunsola, 2014; Ajah and Ajah, 2014; Obasi et al., 2013; Simonyan et al. 2011), improved seeds/planting materials (Anigbogu et al., 2015; Ajah and Ajah, 2014; Obasi et al., 2013), household size (Simonyan et al., 2011), credit access and use (Simonyan et al., 2011), and labour - household or hired (Adeniyi and Ogunsola, 2014; Obasi et al., 2013). Among the variables found to be inversely related to farmers' productivity included age of the farmers (Olukunle, 2016; Ajah and Ajah, 2014; Obasi et al., 2013; Ayoola et al., 2011), gender (Anigbogu et al., 2015), marital status (Ayoola et al. 2011), labour (Olukunle, 2016; Adeniyi and Ogunsola, 2014), planting materials and chemical fertilizer (Obasi et al., 2013).

In their study of cocoa in Osun State, Nigeria, Adeniyi and Ogunsola (2014), in addition to identifying the climatic variables of rainfall, sunshine and temperature also argued that the 
ageing cocoa tree, prevalence of pest and disease, age of cocoa farm, and extra hours spent by farmers after rain, were among the key variables that significantly affect cocoa yield in the area. They recommended use of policies that can mitigate the adverse impact of climate variations in the short-run and education and training of farmers on safety and best practices for the prevention of climatic adversities as a long-term remedy. Also, gender dimension had been brought into the discourse. For example, Ayoola et al. (2011) examined the socioeconomic factors influencing rice production among male and female farmers in Northern Guinea Savanna zone of Nigeria and found that land, variable inputs, and experience had significant and direct influence on productivity for both male and female farmers, but age influenced it negatively, implying that the older rice farmers had less virility for farming. They also found the coefficient for marital status to be negative for women. They attributed that to the fact that married women within reproductive age were more likely to be constrained in their production by their multiple household roles, as well as cultural practices that often prevented them from participating in direct field production activities.

\section{METHODOLOGY OF RESEARCH}

Study area. The study was conducted in eight cassava-growing states that were participants in the cassava starch value chain project implemented on behalf of Nestlé Foods Plc by the International Institute of Tropical Agriculture (IITA) from 2011-2015. Five of the states were classified into the south-east (SE) axis and the remaining three into the southwest (SW) axis. The SE axis comprised of Abia, Anambra, Delta, Enugu and Imo States. Abia State is located at latitude $5.41667^{\circ} \mathrm{N}$ and longitude $07.5000^{\circ} \mathrm{E}$. It had a land area of 6,320 square kilometre, seventeen Local Government Areas (LGAs), and a population of 2,845,380 (50.27\% male and 49.73\% female) based on the 2006 National Population Census. The administrative headquarter of Abia was in Umuahia. Anambra State, located at latitude $6.33333^{\circ} \mathrm{N}$ and longitude $07.0000^{\circ} \mathrm{E}$, had twenty-one LGAs, a land area of 4,844 square kilometres, and a population of $4,177,828$ (50.70\% males and $49.30 \%$ females. The administrative headquarters of Anambra State is in Awka. Delta State with administrative headquarters at Asaba is located at latitude $6.2000^{\circ} \mathrm{N}$ and longitude $6.7300^{\circ} \mathrm{E}$. It had a land area of 17,698 square kilometres, twenty-five LGAs, and a population of $4,112,455(50.32 \%$ males and $49.38 \%$ females. Enugu State with administrative headquarter in Enugu is located at latitude $06.5000^{\circ} \mathrm{N}$ and longitude $07.5000^{\circ} \mathrm{E}$. It had seventeen LGAs, a land area of 7,161 square kilometres, a population of $3,267,837$ (48.84\% males and $51.16 \%$ females), and an rainfall range of $1520-2030 \mathrm{~mm} / a n n u m$. The fifth state, Imo, is located at latitude $5.4800^{\circ} \mathrm{N}$ and longitude $07.0300^{\circ} \mathrm{E}$. It had administrative headquarter in Owerri, twenty-seven LGAs, a land area of Imo State is 5,100 square kilometres, and a population of 3,927,563 $(50.32 \%$ male and $49.68 \%$ female). The SW axis comprised of Ekiti, Ondo and Osun States. Ekiti State with administrative headquarter in Ado-Ekiti is located at latitude $7.6200^{\circ} \mathrm{N}$ and longitude $05.2200^{\circ} \mathrm{E}$. The state had a land size of 6,353 square kilometres, sixteen LGAs, and a population of 2,398,957 (comprising of $50.67 \%$ male and $49.33 \%$ female. Ondo State is located at latitude $07.2500^{\circ} \mathrm{N}$ and longitude $5.1900^{\circ} \mathrm{E}$. It had an area size of 15,500 square kilometres, eighteen LGAs, and a population of $3,460,877$ people (consisting of $50.42 \%$ male and $49.58 \%$ female). Its capital and administrative headquarters was in Akure. The third SW State is Osun with capital city and administrative headquarters at Osogbo. Osun is located at latitude $7.7500^{\circ} \mathrm{N}$ and longitude $4.5610^{\circ} \mathrm{E}$. It had a population of $3,416,959(50.75 \%$ male and $49.25 \%$ female), thirty LGAs, and a land area size of 9,251 square kilometres.

One common feature of the Project States is that they had fertile lands that were good for the production of several foods and cash crops. Cassava and yams, maize, plantain and banana, cocoyam, and sweet potatoes are some of the food security crops produced in these states. Among the common cash crops are palm produce, kolanuts, and cocoa. In addition, these states are endowed with many other natural resources like rivers, lakes, coal, limestone, lead, zinc, fine sand, limestone and petroleum, which can be spotted moving from one state to another. These project locations fell within at most 150 kilometres to the processing centres they were being targeted to service under the project. 
Sample and data collection. This survey was conducted in the 8 project States, which were chosen because of their cassava growing status and involvement in the IITA- Nestlé Foods cassava starch project in Nigeria. The sample comprised of farmers selected from the farmers' clusters using a multi-stage random sampling technique. A cluster was made up of an average of 10 to 20 members and three clusters were randomly selected from each state. Four members were randomly selected and interviewed from each cluster. In all, 96 farmers were interviewed using a structured and pre-tested questionnaire. Data were collected on farmers' characteristics, farming practices, including fertilizer use status, harvesting methods and season and yield. The collected data relate to the 2010/2011 production season.

Analytical techniques. Descriptive and inferential statistics were combined with multivariate regression techniques. The the ordinary least square estimation of the relationship between the endogenous variable and two or more exogenous variables usually produces estimators of the standard error and a coefficient of multiple determination. Suppose a variable $\left(y_{i}\right)$ assumes some values determined by values assumed by other set of variables $\left(x_{i}\right)$. In implicit form, the statement that $y_{i}$ is associated with the $x_{i}$ is given as

$$
y_{i}=f\left(x_{1}, x_{2}, \ldots, x_{k}\right)
$$

where: $y_{i}$ is the dependent variable, and $x_{i}($ for $\mathrm{i}=1, \ldots \mathrm{k})$ is a set of $\mathrm{k}$ explanatory variables.

The coefficient of multiple determination measures the relative amount of variation in the dependent variable $\left(y_{i}\right)$ explained by the regression relationship it has with the explanatory variables $\left(x_{i}\right)$. The F-statistics tests the significance of the coefficients of the explanatory variables as a group, that is, the null hypothesis of no evidence of significant statistical regression relationship between $y_{i}$ and the $x_{i}$ against the alternative hypothesis of evidence of significant statistical relationship. The critical F-value has $n$ and $n-k-1$ degrees of freedom, where $n$ is the number of respondents and $k$ is the number of explanatory variables. The standard error is the measure of error about the regression coefficients. The z-statistics is used in testing the null hypothesis that the parameter estimates are statistically equal to zero against the alternative hypothesis that the parameter estimates are statistically different from zero. If the computed $z$-value exceeds the critical value, we reject the null hypothesis and conclude that the parameter estimates differ significantly from zero.

Empirical model. An empirical model of cassava productivity of the smallholder farmers supplying cassava to the starch processors, was specified as

$$
\begin{aligned}
P R O D_{i}= & \beta_{0}+\beta_{1}\left(F A G E_{i}\right)+\beta_{2}\left(F S Z E_{i}\right)+\beta_{3}\left(V A R T_{i}\right)+\beta_{4}\left(T R A N_{i}\right)+\beta_{5}\left(P R C R_{i}\right)+ \\
& \beta_{6}\left(H S E A_{i}\right)+\beta_{7}\left(F E R T_{i}\right)+\beta_{8}\left(G E N D_{i}\right)+\beta_{9}\left(H H S Z_{i}\right)+\beta_{10}\left(F E R T_{i}\right)+ \\
& \beta_{11}\left(T M D E_{i}\right)+\beta_{12}\left(M R S T_{i}\right)+\zeta_{i}
\end{aligned}
$$

where: $\mathrm{PROD}_{\mathrm{i}}=$ dependent variable, farmer's productivity is defined as the average yield of cassava, given in tonnes/ha. In this study, it is hypothesized that the yield was related to some exogenously determined farmer's characteristics, which were selected on basis of theory and literature evidence; $\beta_{0}=$ constant and intercept of the equation; $\mathrm{FAGE}_{\mathrm{i}}=$ Age of the farmer, measured in years; indeterminate sign (positive or negative) is predicted for farmer's age $\left(b_{1>0}\right.$ or $\left.b_{1<0}\right)$; FSZE $E_{\mathrm{i}}=$ farm size, land area cultivated by respondent during the period (in hectares); a negative sign is predicted for farm size $\left(b_{2}<0\right)$; $\mathrm{VART}_{\mathrm{i}}=$ variety type planted by farmer (dummy): $1=$ improved, $0=$ local or quasi-improved; a positive sign is predicted for VART $\left(b_{3}>0\right)$; TRAN $_{\mathrm{i}}=$ exposure to training (dummy): $1=$ farmer had been exposed to training, $0=$ farmer had not been exposed to training; a positive sign is predicted $\left(b_{4}>0\right) ; \mathrm{PRCR}_{\mathrm{i}}=$ processor credit support to farmer during the season under study (dummy): $1=$ farmer received credit, $0=$ farmer did not receive credit; a positive sign is predicted $\left(b_{5}>0\right)$; 
HSEA $_{\mathrm{i}}=$ harvesting season (dummy): 1=rainy season, $0=$ dry season; a positive sign is predicted for harvesting season because there exists higher probability of root loss due to hardness of the soil during dry season harvest than it will be harvesting at rainy season $\left(b_{6}>0\right) ; \mathrm{GEND}_{\mathrm{i}}=$ gender of farmer (dummy): $1=$ female, $0=$ male; a negative relationship is predicted for gender $\left(b_{7}<0\right)$; $\mathrm{HHSZ}_{\mathrm{i}}=$ household size, number of people resident in the farmer's household; indeterminate sign (positive or negative) is predicted for household size $\left(b_{8}>0\right.$ or $\left.b_{8<0}\right)$; FERT ${ }_{i}=$ fertilizer application status of farmer (dummy: $1=$ fertilizer applied, $0=$ fertilizer not applied); a positive sign is hypothesized for fertilizer application status $\left({ }^{x_{9}}>0\right)$; $\mathrm{TMDE}_{\mathrm{i}}=$ farmer's time devoted to farming (dummy: $1=$ full-time, $0=$ part-time); a positive sign

is predicted for time devoted to farming $\left({ }^{x_{10}}>0\right)$; $\mathrm{MRST}_{i}=$ farmer's marital status (dummy: $1=$ ever married, $0=$ otherwise); a positive sign is hypothesized for the marital status of the farmer $\left(x_{11}>0\right)$; and $\zeta_{i}=$ stochastic error term.

All estimations of the regression parameters relating to the cassava productivity model of equation (2) was done using the Standard Eviews software. All the functional forms were experimented but the linear model was reported because it produced the best fit based on the estimated values of the coefficient of multiple determinations $\left(R^{2}\right)$ and F-statistics.

\section{RESULTS OF RESEARCH}

Descriptive statistics of variables. The descriptive statistics and coefficients of correlation of the variables are presented in Table 1.

The average age of the farmers is 48.06 years with a standard deviation of 9.53 . The observed average age of 48 years is slightly on the high side compared with the average age of 42.9 years found by Ojiako et al. (2015) for rural cassava farmers that received loan in Ogun State, Nigeria and 45.7 years found by Rahman et al. (2016) for leaf farmers in the Teknaf Peninsula, Bangladesh. Also, the averages for farming experience, farm size and household size are 15.88 years, 3.16 ha and 7.41 persons with standard deviations of 10.51 , 2.95 and 3.20 respectively. Majority of the other variables presented in Table 1 were measured as dummies, meaning that their averages should be interpreted as proportions. For example, it can be read from the Table that $23 \%$ of the farmers were women, $89 \%$ were married and $54 \%$ reported that they applied fertilizer on their farms during the period under study.

Analysis of farmers' yield. The average on-farm yield obtained from sample harvesting of selected fields in each of the project States was presented in Figure 2.

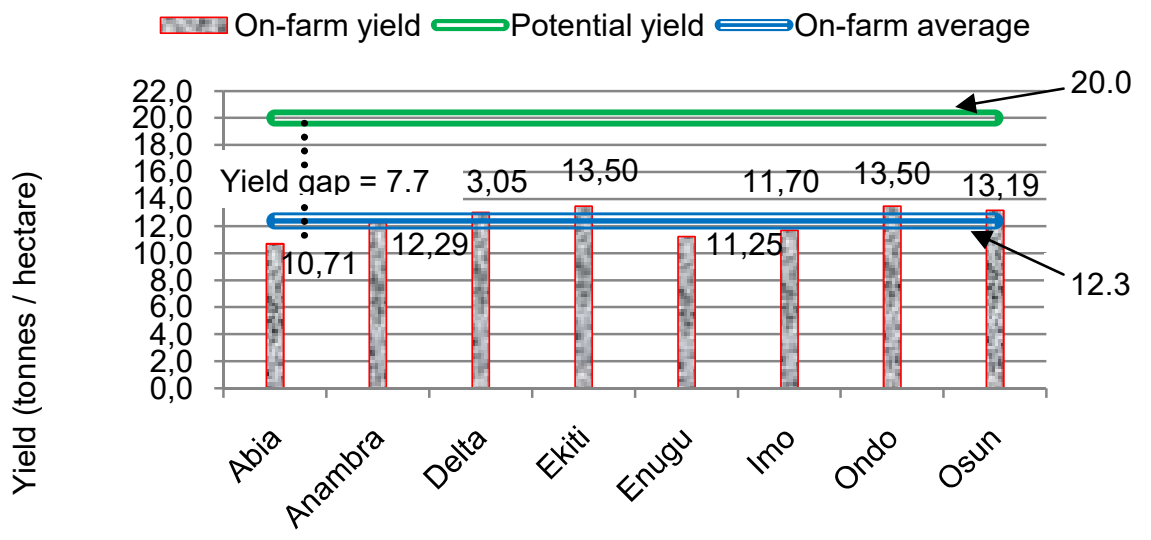

Project States

Figure 2 - Comparing farmers' on-farm yield with potential yield of improved varieties 
RJOAS, 2(62), February 2017

Table 1 - Descriptive statistics and correlation matrix of variables

\begin{tabular}{|c|c|c|c|c|c|c|c|c|c|c|c|c|c|c|c|c|}
\hline \multirow{2}{*}{ Variables } & \multicolumn{2}{|c|}{ Descriptives $(n=96)$} & \multicolumn{14}{|c|}{ Pearson coefficients of correlation (2-tails) } \\
\hline & Mean & Std. dev. & EXPR & EDUC & FMSZ & VART & TRAN & PRCR & HSEA & GEND & HHSZ & FERT & TMDE & MRST & RACC & HMTH \\
\hline FAGE & 48.06 & 9.53 & $\begin{array}{l}0.627 \\
(0.000)\end{array}$ & $\begin{array}{c}0.033 \\
(0.749)\end{array}$ & $\begin{array}{c}0.088 \\
(0.393)\end{array}$ & $\begin{array}{l}0.191 \\
(0.062)\end{array}$ & $\begin{array}{l}-0.113 \\
(0.272)\end{array}$ & $\begin{array}{l}-0.133 \\
(0.195)\end{array}$ & $\begin{array}{l}-0.158 \\
(0.124)\end{array}$ & $\begin{array}{c}0.082 \\
(0.427)\end{array}$ & $\begin{array}{l}0.596 \\
(0.000)\end{array}$ & $\begin{array}{l}0.240 \\
(0.019)\end{array}$ & $\begin{array}{l}-0.023 \\
(0.849)\end{array}$ & $\begin{array}{l}-0.050 \\
(0.681)\end{array}$ & $\begin{array}{l}-0.023 \\
(0.849)\end{array}$ & $\begin{array}{l}-0.060 \\
(0.615)\end{array}$ \\
\hline EXPR & 15.88 & 10.51 & - & $\begin{array}{l}-0.169 \\
(0.102)\end{array}$ & $\begin{array}{l}-0.050 \\
(0.625)\end{array}$ & $\begin{array}{l}0.252 \\
(0.013)\end{array}$ & $\begin{array}{c}-0.313^{x} \\
(0.002)\end{array}$ & $\begin{array}{c}-0.063 \\
(0.543)\end{array}$ & $\begin{array}{c}-0.285^{1} \\
(0.005)\end{array}$ & $\begin{array}{c}0.079 \\
(0.445)\end{array}$ & $\begin{array}{l}0.560 \\
(0.000)\end{array}$ & $\begin{array}{l}0.187^{\prime} \\
(0.068)\end{array}$ & $\begin{array}{l}-0.126 \\
(0.291)\end{array}$ & $\begin{array}{l}-0.094 \\
(0.437)\end{array}$ & $\begin{array}{l}-0.126 \\
(0.291)\end{array}$ & $\begin{array}{l}-0.089 \\
(0.457)\end{array}$ \\
\hline EDUC & 2.87 & 0.85 & - & - & $\begin{array}{c}0.094 \\
(0.364)\end{array}$ & $\begin{array}{c}0.016 \\
(0.878)\end{array}$ & $\begin{array}{l}0.215^{*} \\
(0.037)\end{array}$ & $\begin{array}{c}0.039 \\
(0.710)\end{array}$ & $\begin{array}{c}0.014 \\
(0.894)\end{array}$ & $\begin{array}{c}0.036 \\
(0.730)\end{array}$ & $\begin{array}{c}0.119 \\
(0.255)\end{array}$ & $\begin{array}{l}-0.135 \\
(0.191)\end{array}$ & $\begin{array}{c}0.033 \\
(0.784)\end{array}$ & $\begin{array}{l}-0.159 \\
(0.187)\end{array}$ & $\begin{array}{c}0.033 \\
(0.784)\end{array}$ & $\begin{array}{l}-0.063 \\
(0.604)\end{array}$ \\
\hline FMSZ & 3.16 & 2.95 & - & - & - & $\begin{array}{l}-0.053 \\
(0.606)\end{array}$ & $\begin{array}{l}0.211^{*} \\
(0.039)\end{array}$ & $\begin{array}{l}-0.002 \\
(0.985)\end{array}$ & $\begin{array}{l}0.281 \\
(0.0060\end{array}$ & $\begin{array}{l}0.209^{*} \\
(0.041)\end{array}$ & $\begin{array}{c}0.023 \\
(0.822)\end{array}$ & $\begin{array}{c}0.106 \\
(0.305)\end{array}$ & $\begin{array}{l}-0.209^{4} \\
(0.078)\end{array}$ & $\begin{array}{l}-0.158 \\
(0.187)\end{array}$ & $\begin{array}{l}-0.209 \\
(0.078)\end{array}$ & $\begin{array}{l}-0.066 \\
(0.585)\end{array}$ \\
\hline VART & 0.21 & 0.41 & - & - & - & - & $\begin{array}{l}-0.021 \\
(0.836)\end{array}$ & $\begin{array}{l}-0.132 \\
(0.198)\end{array}$ & $\begin{array}{l}-0.060 \\
(0.561)\end{array}$ & $\begin{array}{c}0.036 \\
(0.731)\end{array}$ & $\begin{array}{l}0.250^{*} \\
(0.015)\end{array}$ & $\begin{array}{l}0.214^{* 4} \\
(0.036)\end{array}$ & $\begin{array}{l}-0.094 \\
(0.430)\end{array}$ & $\begin{array}{l}-0.189 \\
(0.114)\end{array}$ & $\begin{array}{l}-0.094 \\
(0.430)\end{array}$ & $\begin{array}{l}-0.094 \\
(0.432)\end{array}$ \\
\hline TRAN & 0.72 & 0.45 & - & - & - & - & - & $\begin{array}{l}-0.030 \\
(0.772)\end{array}$ & $\begin{array}{l}0.343^{3} \\
(0.001)\end{array}$ & $\begin{array}{c}0.100 \\
(0.333)\end{array}$ & $\begin{array}{l}-0.069 \\
(0.505)\end{array}$ & $\begin{array}{c}0.029 \\
(0.779)\end{array}$ & $\begin{array}{l}-0.167 \\
(0.161)\end{array}$ & $\begin{array}{l}-0.028 \\
(0.819)\end{array}$ & $\begin{array}{l}-0.167 \\
(0.161)\end{array}$ & $\begin{array}{l}-0.049 \\
(0.683)\end{array}$ \\
\hline PRCR & 0.06 & 0.24 & - & - & - & - & - & - & $\begin{array}{c}0.022 \\
(0.835)\end{array}$ & $\begin{array}{l}-0.064 \\
(0.536)\end{array}$ & $\begin{array}{l}-0.047 \\
(0.650)\end{array}$ & $\begin{array}{l}-0.022 \\
(0.835)\end{array}$ & $\begin{array}{c}0.098 \\
(0.415)\end{array}$ & $\begin{array}{l}-0.057 \\
(0.634)\end{array}$ & $\begin{array}{c}0.098 \\
(0.415)\end{array}$ & $\begin{array}{l}-0.029 \\
(0.812)\end{array}$ \\
\hline HSEA & 0.46 & 0.50 & - & - & - & - & - & - & - & $\begin{array}{c}0.104 \\
(0.315)\end{array}$ & $\begin{array}{c}-0.337 \\
(0.001)\end{array}$ & $\begin{array}{l}0.175 \\
(0.088)\end{array}$ & $\begin{array}{l}-0.204^{2} \\
(0.085)\end{array}$ & $\begin{array}{l}-0.086 \\
(0.476)\end{array}$ & $\begin{array}{l}-0.204 \\
(0.085)\end{array}$ & $\begin{array}{l}-0.120 \\
(0.317)\end{array}$ \\
\hline GEND & 0.23 & 0.42 & - & - & - & - & - & - & - & - & $\begin{array}{l}0.204^{2 *} \\
(0.047)\end{array}$ & $\begin{array}{l}-0.054 \\
(0.602)\end{array}$ & $\begin{array}{c}0.127 \\
(0.286)\end{array}$ & $\begin{array}{c}0.104 \\
(0.386)\end{array}$ & $\begin{array}{c}0.127 \\
(0.286)\end{array}$ & $\begin{array}{c}0.101 \\
(0.398)\end{array}$ \\
\hline HHSZ & 7.41 & 3.20 & - & - & - & - & - & - & - & - & - & $\begin{array}{c}0.107 \\
(0.304)\end{array}$ & $\begin{array}{c}0.016 \\
(0.894)\end{array}$ & $\begin{array}{l}-0.081 \\
(0.506)\end{array}$ & $\begin{array}{c}0.016 \\
(0.894)\end{array}$ & $\begin{array}{c}0.093 \\
(0.440)\end{array}$ \\
\hline FERT & 0.54 & 0.50 & - & - & - & - & - & - & - & - & - & - & $\begin{array}{l}-0.096 \\
(0.421)\end{array}$ & $\begin{array}{l}-0.303 \\
(0.010)\end{array}$ & $\begin{array}{l}-0.096 \\
(0.421)\end{array}$ & $\begin{array}{l}-0.009 \\
(0.938)\end{array}$ \\
\hline TMDE & 0.32 & 0.47 & - & - & - & - & - & - & - & - & - & - & - & $\begin{array}{l}-0.005 \\
(0.959)\end{array}$ & $\begin{array}{l}0.998 \\
(0.000)\end{array}$ & $\begin{array}{l}0.260 \\
(0.010)\end{array}$ \\
\hline MRST & 0.89 & 0.32 & - & - & - & - & - & - & - & - & - & - & - & - & $\begin{array}{l}-0.005 \\
(0.959)\end{array}$ & $\begin{array}{c}0.148 \\
(0.153)\end{array}$ \\
\hline RACC & 0.32 & 0.47 & - & - & - & - & - & - & - & - & - & - & - & - & - & $\begin{array}{l}0.260 \\
(0.010)\end{array}$ \\
\hline HMTH & 0.03 & 0.17 & - & - & - & - & - & - & - & - & - & - & - & - & - & - \\
\hline
\end{tabular}

FAGE=age of respondent; EXPR=years of (farming) experience; EDUC=level of education; FMSZ=farm size; VART=variety type (dummy); TRAN=training (dummy); PRCR=processor credit support (dummy); HMTH=harvesting method (dummy); HSEA=harvesting season (dummy); RACC=road access (dummy); GEND=gender of respondent; HHSZ=household size; MRST=marital status, and TMDE=farmer's time devoted to cassava farming. Exchange rate of the naira (Nigeria local currency) to the USA dollars was US\$1/N150.

${ }^{* *} .=$ significant at $1 \% ;{ }^{* *} .=$ significant at $5 \% ;{ }^{*} .=$ significant $10 \%$ 
The average yield was calculated to be $12.3 \mathrm{t}$. The average yields for the states were calculated as follows: Abia (10.7 t/ha), Anambra (12.3 t/ha), Delta (13.0 t/ha), Ekiti (13.5 t/ha), Enugu (11.2 t/ha), Imo (11.7 t/ha), Ondo (13.5 t/ha) and Osun (13.2 t/ha). It follows that on-farm yield was lowest in Abia and highest in Ondo and Ekiti States. Further investigations were conducted to ascertain the possible cause of relativity in yields among the States. It was discovered that the SW States of Ekiti, Ondo and Osun had previously benefitted from out-growers scheme arrangements under different projects. Among these were the cassava value chain projects sponsored by USAID under the USAID-Nigeria Maximizing Agricultural Revenues and Key Enterprises in Targeted Sites (MARKETS) and the USAID-Nigeria Maximizing Agricultural Revenues and Key Enterprises in Targeted Sites II (BtM2) projects implemented from 2009-2011 seasons under an out-growers scheme with MATNA Foods Company, a commercial starch processing factory located in Akure, Ondo State. Part of the strategies used under the schemes was empowerment and capacity building of the enlisted farmers by way of providing improved cassava stems, training on improved farm management practices, and linkage to sources of micro-credit.

Notwithstanding, Figure 2 still shows the existence of a yield gap of $7.7 \mathrm{t} / \mathrm{ha}$ when the calculated yield is compared with the expected minimum yield of $20 \mathrm{t} / \mathrm{ha}$, which was being promoted under the IITA- Nestlé Foods cassava value chain project. This means that there was still much room for improvement of the farmers' yield performances. One of the expectations of this Nestlé Project was to close the existing yield gap by raising the farmers' on-farm yield to at least $20 \mathrm{t} / \mathrm{ha}$ so as to be able supply efficiently to the processors to boost their starch production and supply capacity to Nestlé Foods Plc. Also the higher yields would result to increased income and improved welfare for the cassava farming households.

Determinants of productivity among farmers. The regression output is presented in this section. It should be noted that not all the farmers characteristics examined in the previous section could were used for the regression analysis. The choice of included variables was based on relevance and empirical evidence from literature. The regression output is presented in Table 2.

Table 2 - Determinants of productivity among cassava farmers

\begin{tabular}{|c|c|c|c|c|c|}
\hline Variable & Code & Coefficient & Std. Error & t-Statistic & Prob. \\
\hline Constant & $\operatorname{CON}\left(\beta_{0}\right)$ & $6.567^{n n}$ & 1.916 & 3.428 & 0.001 \\
\hline Age of farmer (years) & FAGE & -0.039 & 0.045 & -0.871 & 0.386 \\
\hline Farm size (area planted) (ha) & FSZE & -0.003 & 0.073 & -0.048 & 0.961 \\
\hline Variety type $(0,1)$ & VART & $13.018^{\pi \times \pi}$ & 1.549 & 8.404 & 0.000 \\
\hline Exposure to training $(0,1)$ & TRAN & $1.810^{\pi}$ & 1.087 & 1.666 & 0.099 \\
\hline Processor credit received $(0,1)$ & PRCR & $1.106^{\pi}$ & 0.575 & 1.924 & 0.057 \\
\hline Harvesting season $(0,1)$ & HSEA & 0.455 & 0.659 & 0.690 & 0.491 \\
\hline Gender of respondent $(0,1)$ & GEND & -0.706 & 0.941 & -0.749 & 0.455 \\
\hline Household size (numbers) & HHSZ & 0.265 & 0.164 & 1.616 & 0.109 \\
\hline Fertilizer use by respondent $(0,1)$ & FERT & 0.392 & 0.641 & 0.611 & 0.542 \\
\hline Time devoted to farming $(0,1)$ & TMDE & $1.236^{\star *}$ & 0.618 & 2.000 & 0.048 \\
\hline Marital status of respondent $(0,1)$ & MRST & $1.493^{x}$ & 0.866 & 1.724 & 0.088 \\
\hline R-squared & & 0.754 & \multicolumn{2}{|c|}{ Mean dependent variable } & 12.33 \\
\hline Adjusted R-squared & & 0.721 & \multicolumn{2}{|c|}{ S.D. dependent var } & 6.417 \\
\hline S.E. of regression & & 3.388 & \multicolumn{2}{|c|}{ Akaike info criterion } & 5.396 \\
\hline Sum squared residuals & & 952.585 & \multicolumn{2}{|c|}{ Schwarz criterion } & 5.718 \\
\hline Log likelihood & & -244.301 & \multicolumn{2}{|c|}{ F-statistic } & 23.112 \\
\hline Durbin-Watson stat & & 1.780 & \multicolumn{2}{|c|}{ Prob (F-statistic) } & 0.000 \\
\hline
\end{tabular}

Note: Estimates are heteroskedatic-consistent with Newey-West HAC Standard Errors \& Covariance.

. = significant at $1 \% ;{ }^{* *} .=$ significant at $5 \% ;{ }^{*} .=$ significant $10 \%$.

The dependent variable is yield of cassava, given in tonnes/ha. The regression output has revealed the model to be highly significant $\left[F-v a l u e=23.11(p<0.01)\right.$; Adjusted $R^{2}=$ 0.721]. This implies that the included variables explained $72.1 \%$ of the variations in the estimated yield model.

This coefficient of determination is by far higher than $47.2 \%$ obtain by Adesoji and Farinde (2006) in their investigation of the influence of farmers' socioeconomic variables on 
the yield of arable crops in Osun State, Nigeria. The use of improved cassava variety (VART) and time devoted to farming (TMDE) were statistically significant at $1 \%$ and $5 \%$ levels respectively, making them very conspicuous among the factors explaining variations in the yield. Three other variables were also significant at $10 \%$ levels, including exposure to trainings (TRAN), use of credit facility from processor (PRCR) and marital status (MRST) of the farmer.

All the significant variables had the predicted positive signs, meaning that cassava yields increased with positive changes in these determinants. The other variables with positive signs although not significant were harvesting season (HSEA), household size (HHSZ), and fertilizer application (FERT). The remaining variables, namely, age of the farmer (FAGE), farm size (FSZE) and gender (GEND) returned negative signs, but were also not statistically significant.

Responsiveness of yield to changes in the variables. The responsiveness of yield to changes in the explanatory variables were calculated as coefficients of elasticity and presented in Table 3. Although elasticity was calculated for all variables, only the significant ones will be discussed.

Table 3 - Yield responsiveness to changes in variables

\begin{tabular}{lll}
\hline & Variable & Elasticity coefficient \\
\hline Age of farmer (years) & FAGE & 0.152 \\
Farm size (area planted) (ha) & FSZE & 0.001 \\
Variety type $(0,1)$ & VART & $0.222^{\star \pi \pi}$ \\
Exposure to training $(0,1)$ & TRAN & $0.106^{\star}$ \\
Processor credit received $(0,1)$ & PRCR & $0.005^{\star}$ \\
Harvesting season $(0,1)$ & HSEA & 0.017 \\
Gender of respondent $(0,1)$ & GEND & 0.044 \\
Household size (numbers) & HHSZ & 0.159 \\
Fertilizer use by respondent $(0,1)$ & FERT & 0.017 \\
Time devoted to farming $(0,1)$ & TMDE & $0.032^{\star \pi}$ \\
Marital status of respondent $(0,1)$ & MRST & $0.108^{\star}$ \\
\hline
\end{tabular}

${ }^{* * *}$. significant at $1 \% ;{ }^{* *} .=$ significant at $5 \% ;{ }^{*} .=$ significant $10 \%$.

The coefficient of elasticity was 0.222 for use of improved variety, 0.032 for time devoted to farming, 0.106 for attendance to training, 0.005 for use of processor's credit facility and 0.108 for marital status. This means that a $10 \%$ increase in the proportion of farmers who could access and use the improved variety would result to about $2.22 \%$ increase in cassava yield other factors remaining constant. A similar $10 \%$ increase in the proportion of farmers who are into full-time farming, or attended to training, or received credit facility, or were married as against being single, would result to an increase in cassava yield by $3.3 \%, 1.06 \%, 0.055$ and $1.08 \%$ respectively. It can be inferred from the result that the degree of responsiveness of cassava yield to changes in each of these significant explanatory variables was inelastic.

\section{DISCUSSION OF RESULTS}

Part of the findings of this investigation is the significant positive influence of use of improved cassava varieties to boost yield outcome. So much benefits are associated with the use of improved planting materials causing their inclusion in the recommended package of practices (PoPs). The improved varieties of cassava were cloned to be high-yielding, early maturing, and resilience to attacks of pests and diseases. Their use gives the farmer a good value for money, while the consequence of farmers' continued use of the local varieties is low yield performance, low output, low income and waning welfare. This finding is corroborated by Anigbogu et al. (2015) whose investigation of the socioeconomic factors influencing agricultural production among cooperative farmers in Anambra State, Nigeria, found that the planting materials (seedlings) obtained through cooperatives were among the factors with significant influence. Membership of cooperative groups has been encouraged among 
farmers as instruments of social and economic transformation (ljere, 1992). Among other things cooperatives have served as channels through which technology dissemination to farmers could yield maximum results. Also, Obasi et al. (2013) analyzed the factors affecting agricultural productivity among arable crop farmers in Imo State, Nigeria and among other things recognised the influence of planting materials and consequently, recommended the use of high yielding planting materials to boost farmers' productivity.

Findings from this study also revealed that full-time farming had a significant influence on productivity. This is not surprising given that full-time farmers devote more time, energy and resources to get the best out of their farms compared with part-time farmers who share their time and resources pursuing so many things at the same time. It could have resulted from the fact that full-time farmers were bound to be more efficient through continuous learning from day-to-day experiences, demonstration of best practices to improve on their performance, and fashioning out ways of conducting their farming activities better, given that they were not prepared to trade-off their time and resources by going into other livelihood options. Onemolease and Ataraire (2005) in an investigation of the influence of household and farm-related characteristics on farm enterprise productivity in the guinea corn value chain in Okene and Kogi Local Government Areas of Kogi State, Nigeria also found that fulltime farming was significant and impacted positively to farmers' productivity. Contrarily, however, Lien et al. (2008) in their examination of determinants of part-time farming and its effects on on-farm productivity and efficiency, could not establish any systematic difference in farm productivity and technical efficiency between the part-time and full-time farmers.

Training was also found to have a positive influence on cassava farmers' productivity. In their investigation of the influence of farmers' socioeconomic variables on the yield of arable crops in Osun State, Nigeria, Adesoji and Farinde (2006) also found that training and demonstrations attended by farmers had significant positive influence on yield performance of arable crops. In the same vein, Ibitoye and Onimisi (2013) analyzed the effect of training programmes on farmers' productivity in poultry production in Kogi State, Nigeria and found that both extension training and formal education were significant positive contributors to productivity, which they measured as farm income. In this study, although both training and formal education have positive signs only training was significant in explaining productivity. This finding underscores the need to incorporate and sustain regular training, field days, and regular extension support services among the package of practices being delivered to farmers to enhance their yield outcomes.

Marital status of farmers was also a significant determinant. Positively related to productivity, the result suggested that productivity was more for farmers living with their spouses than it was for farmers not with spouses. This finding underscores the benefit derivable from complementary roles of male and female farmers in promotion of cassava value chain. It has been succinctly argued that the activities of cassava production, marketing, and processing in most rural Nigerian communities were jointly performed by men and women, who had complementary obligations for providing food for the Nigerian rural household (Ezumah and Di Domenico, 1995; Das, 1995; Anyakoha and Ozoh, 1999). Elsewhere, Simonyan et al. (2011) assesed the productivity of maize farmers in Essien Udim Local Government Area of Akwa-lbom State, Nigeria, in terms of assessing efficiency and its determinant on gender basis. With respect to the male farmers, the study identified marital status among the variables with significant positive influence, although it was not significant with respect to female farmers. But in another study, Ayoola et al. (2011) found that the effect of marital status of married women's on rice productivity was negative, implying that they were more likely to be constrained in their production of rice in view of their multiple roles and the cultural practices that prevent women from direct field production activities.

Generally, the use credit facility to support farmers has been advocated because credit plays an enviable role in economic transformation and rural development (Ojiako et. al., 2015; Ojiako and Ogbukwa, 2012). Defined as the process of having control over the use of others' money, goods and/or services in the present in exchange for a promise to repay at a future date (Adegeye and Dittoh, 1985), agricultural or farm credit was a crucial input required by the smallholder farmers to establish and expand their farms with the aim of 
increasing agricultural production, enhancing food sufficiency, promoting household and national income, and augmenting the individual borrower's ability to repay (Ojiako and Ogbukwa, 2012). No doubt, the limitations of self-finance, uncertainties associated with the levels of output, and time lag between inputs acquisition-cum-use and output realization, provide justification for the request for and use of farm credit (Kohansal and Mansoori, 2009). Therefore, it is not surprising that the impact of farmer's access to the processor-provided credit facility could be overwhelming in its contribution to yield and productivity performance of cassava farmers. Whether received in the form of cash or input-credit, such facility provides additional empowerment thereby boosting the smallholder farmers' capacity to use improved planting materials, apply fertilizer and herbicides and pay for labour services. Depending on the nature and timing of the credit facility, it could also assist the farmer to mechanize some of the pre-planting tedious activities of ploughing, harrowing and ridging. In addition to saving cost, the farmer's yield would also be increased. However, in their study of arable crops in Osun State, Adesoji and Farinde (2006) found that the effect of use of credit was negative and weak, which was rather strange.

\section{CONCLUSION}

The socio-economic and other household characteristics of farmers supplying cassava roots to the two commercial starch processors in Nigeria were analyzed alongside their yield performances with a view to determining the relationship between yield and the farmers' characteristics. It was found that although over $70 \%$ of the farmers were using improved varieties, there was still a substantial yield gap, resulting from the farmers' inability to achieve the minimum expected yield from use of improved species, if they had followed the recommended best farming practices. The improved varieties' use status, engagement in fulltime farming, attendance to training, use of credit, and marital status of farmers were identified as factors with positive influence on their level of productivity.

Although much has been documented on the benefits accruing from use of the improved varieties of cassava planting materials to boost yield and productivity, there is need for rigorous extension efforts at ensuring availability, accessibility, adoption, and continuous use of the improved cuttings. Findings of this study suggest that the use high-yielding cuttings was not sufficient on itself, rather it will be accompanied by rigorous but appropriate capacity enhancement programmes, including regular use of workshops, seminars, public enlightenment, and training and retraining sessions and events to get the farmers up to date with emerging issues in cassava production and farm management. In the same vein, it is needful to empower farmers through linkage to sources of soft loan and other microcredit facilities, but as finding from this study also suggests, targeting of the married and full-time farmers will be more impactful than otherwise. The aforementioned findings underscore the need for policies and programmes aimed at enhancing levels of productivity through yield increases to target the identified essential factors. The findings were definitely expected to be very useful in the successful implementation of the IITA- Nestlé Foods cassava starch project to the benefit of the farmers, processors, and other stakeholders in Nigeria's cassava industry.

\section{REFERENCES}

1. Adegeye, A. J. and Dittoh, J. S. (1985). Essentials of Agricultural Economics. Impact Publishers Economics Nigeria, Limited, Ibadan. In: Adebayo, O.O. and Adeola, R.G. 2008. Sources and uses of agricultural credit by small scale farmers in Surulere Local Government Area of Oyo State. Anthrop. 10(4):313-314.

2. Adeniyi, O.R. and Ogunsola, G.O. (2014).Cocoa Production and Related SocialEconomic and Climate Factors: A Case Study of Ayedire Local Government Area of Osun State, Nigeria. Agricultural Science, 2(4): 1-13. 
3. Adesoji, S.A. and Farinde, A.J. (2006). Socio-economic factors influencing yield of arable crop in Osun State, Nigeria. Asian Journal of Plant Sciences, 5 (4): 630-634. ISSN 16823974.

4. Aina, O.O., Dixon, A.G.O. and Akinrinde, E.A. (2007). Effect of Soil Moisture Stress on Growth and Yield of Cassava in Nigeria. Pakistan Journal of Biological Sciences, 10: 3085-3090.

5. Ajah, J. and Ajah, F.C. (2014). Socio-economic determinants of small-scale rice farmers' output in Abuja, Nigeria. Asian Journal of Rural Development, 4(1): 16-24.

6. Ajewole, O.I. and Aiyeloya, A.A. (2004). Soco-economic analysis of benefits of Ibadan Forest Reserves. Journal of Tropical Forest Resources, 20: 95-105.

7. Anigbogu, T.U., Agbasi, O.E. and Okoli, I.M. (2015). Socioeconomic factors influencing agricultural production amongcooperative farmers in Anambra State, Nigeria. International Journal of Academic Research in Economics and Management Sciences, 4 (3): 43-58.

8. Anyakoha, E.U. and Ozoh, R.O. (1999). "Environmental Awareness of Rural Nigerian Women in Enugu State Through Appropriate Agricultural Extension Programs." Issues in African Rural Development Monograph Series, Monograph \# 13, June 1999. Winrock International Institute for Agricultural Development, Morrilton, WIS, USA.

9. Ayoola, J.B., Dangbegnon, C., Daudu, C.K., Mando, A., Kudi, T.M., Amapu, I.Y., Adeosun, J.O. and Ezui, K.S. (2011). Socio-economic factors influencing rice production among male and female farmers in Northern Guinea Savanna Nigeria: lessons for promoting gender equity in action research. Agriculture and Biology Journal of North America, 2(6): 1010-1014.

10. Das, M.D. (1995). Improving the Relevance and Effectiveness of Agricultural Extension Activities for Women Farmers. Rome: Food and Agriculture Organization of the United Nations.

11. Ezumah, N. N. and Di Domenico, C.M. (1995). "Enhancing the Role of Women in Crop Production: A Case of Igbo Women in Nigeria". World Development, 23 (10), 1995, pp. 1731-1744.

12. FAO (2013). Save and Grow: Cassava - A guide to sustainable production intensification. Food and Agriculture Organization of the United Nations, Rome. E-ISBN 978-92-5-107642-2 (PDF). Available on http://www.fao.org/3/a-i3278e.pdf, accessed on 4 August 2016.

13. FAO (2012). FAOSTAT. Food and Agriculture Organization of the United Nations. In: http://faostat.fao.org/site/339/default.aspx, accessed on September 7, 2012.

14. Ibekwe, U.C., Eze, C.C., Ohajianya, D.O., Orebiyi, J.S., Onyemauwa, C.S. and Korie, O.C. (2010). Determinants of non-farm income among farm households in South-east Nigeria. Academia Arena, 2(10): 29-33.

15. Ibitoye, S.J. and Onimisi, J.A. (2013). Influence of Training on Farmer's Productivity in Poultry Production in Kogi State, Nigeria. International Journal of Poultry Science, 12 (4): 239-244.

16. Ijere, M.O. (1992). Prospects of Nigerian Cooperatives. Enugu. ACENA Publishers. In: Ofuoku, A.U. and Urang, E. (2009). Effect of cohesion on loan repayment in farmers' cooperative societies in Delta State, Nigeria. International Journal of Sociology and Anthropology, 1 (4): 070-076.

17. Ikwelle, M.C., Ezulike, T.O. and Eke-Okoro, O.N. (2003). Contribution of root and root crops to the Nigerian economy. Proceedings of the Eight Triennial Symposium of the International Society for Tropical Root Crops - Africa Branch (ISTRC - AB) held at the International Institute of Tropical Agriculture, Ibadan, November 12-16, 2001, pp. 13-18.

18. Kohansal, M.R. and Mansoori, H. (2009). Factors Affecting loan Repayment Performance of Farmers in Khorasan-Razavi Province of Iran. Paper presented at the Conference on International Research on Food Security, Natural Resource Management and Rural Development, University of Hamburg, October 6-8, 2009.

19. Lien, G.D., Kumbhakar, S.C. and Hardaker, J.B. (2008). Determinants of part-time farming and its effect on farm productivity and efficiency. European Association of 
Agricultural Economists (EAAE) 107th Seminar on "Modelling of Agricultural and Rural Development Policies", Sevilla, Spain, 30 January - 1 February 2008, pp. 1-17.

20. Nweke, F.I., Lynam, J. and Prudencio, C. (1995). Collaborative Study of Cassava in Africa (COSCA), Paper No. 3, IITA Publication, 23pp.

21. Obasi, P.C., Henri-Ukoha, A., Ukewuihe, I.S. and Chidiebere-Mark, N.M. (2013). Factors Affecting Agricultural Productivity among Arable Crop Farmers in Imo State, Nigeria. American Journal of Experimental Agriculture, 3(2): 443-454, 2013. Accessed from website: https://www.academia.edu, 31 May 2016.

22. Ojiako, I.A., Okechukwu, R.U. and Olaitan, T. (2015). Econometric analysis of loan repayment competence of smallholder cassava farmers in Yewa area, Ogun State, Nigeria. Journal of Food, Agriculture \& Environment, Vol.13 (3\&4): 158 - 167.

23. Ojiako, I.A., Okechukwu, R.U., Tarawali, G., Idowu, A.O. and Akwarandu, B. (2014). Influence of agronomic and climatic factors on root crop's production: an econometric estimation of cassava supply response in Nigeria, 1961-2008. Research on Crops (An International Journal), Vol. 15 (4): 922-035. ISSN 0972-3226.

24. Ojiako, I.A. and Ogbukwa, B. C. (2012). Economic analysis of loan repayment capacity of small-holder cooperative farmers in Yewa North Local Government Area of Ogun State, Nigeria. African Journal of Agricultural Research (AJAR), 7(13): 2051-2062.

25. Olukunle, O.T. (2016). Socio-economic determinants and profitability of cassava production in Nigeria. International Journal of Agricultural Economics and Extension, 4(4): 229-249.

26. Oluyole, K.A. and Sanusi, R.A. (2009). Socio-economic variables and cocoa production in Cross River State, Nigeria. J. Hum Ecol, 25 (1): 5-8.

27. Onemolease, E.A. and Ataraire, G. (2005). Influence of household and farm-related characteristics on farm enterprise productivity: the case of guinea corn in Okene and Kogi LGAs of Kogi State, Nigeria. The Nigerian Academic Forum, 9 (3): 24-31., October 2005

28. Onwueme, I.C. (1978). The Tropical Root Crops. Chichester: John Wiley and Sons. In: Ezedinma, C., OJIAKO, I.A., Okechukwu, R.U., Lemchi, J., Umar, A.M., Sanni, L., Akoroda, M., Ogbe, F., Okoro, E., Tarawali, G. and Dixon, A. (2007). The cassava food commodity market and trade network in Nigeria. International Institute of Tropical Agriculture (IITA), Ibadan, Nigeria.

29. Phillips, T.P., Taylor, D.S., Sanni, L. and Akoroda, M.O. (2004). A cassava industrial revolution in Nigeria: The potential for a new industrial crop. Food and Agriculture Organization (FAO) of the United Nations. Rome, Italy.

30. Rahman, M.A., Tani, M. and Tsuruta, H. (2016). Socioeconomic Characteristics of the Betel Leaf Farmers in the Teknaf Peninsula, Bangladesh. Asian Journal of Agricultural Extension, Economics \& Sociology, 11 (3): 1-8, 2016; ISSN: 2320-7027.

31. Simonyan, J.B., Umoren, B.D., and Okoye, B.C. (2011). Gender differentials in technical efficiency among maize farmers in Essien Udim Local Government Area, Nigeria. International Journal of Economics and Management Sciences, 1(2): 17-23

32. Schreinemachers, P., Wu, M., Uddin, M.N., Ahmad, S. and Hanson, P. (2016). Farmer training in off-season vegetables: Effects on income and pesticide use in Bangladesh. Food Policy, 61: 132-140.

33. UNIDO (2006). A Strategic Action Plan for Development of the Nigerian Cassava Industry: Cassava Master Plan. Prepared by the United Nations Industrial Development Organization in Cooperation with the Ministry of Trade and Industry and the Presidential Initiative on Cassava. 